Journal of Jungian Scholarly Studies

Vol. 5, No. 2, 2009

\title{
Ego Readings vs. Reading for Psyche
}

Inez Martinez, PhD

In The Spirit in Man, Art, and Literature, Jung made a startling claim for "visionary" imaginative literature. Ascribing the source of art to the "collective unconscious" ("The Relation of Analytical Psychology to Poetry" par. 125), he asserts that visionary literature functions for the collective as dreams do for individuals; it presents needed compensatory vision to collective consciousness ("Psychology and Literature" pars. 161-62). In other words, he claims that visionary imaginative literature has the power to help the collective psyche selfregulate.

Reflecting on that claim and on human history, I cannot help but question literature's efficacy as a compensatory force. But perhaps the trouble, so to speak, lies not in the literature, but in the readers. If we read with rigid ego boundaries, we are performing what I call ego readings, thus cutting ourselves off from unconscious contents in imaginative literature. I wish to explore causes and kinds of ego readings and to suggest some ways to slip free of them so that we may read for psyche.

Jung advises us that to benefit from the vision made accessible to collective consciousness in art we must "let a work of art act upon us as it acted upon the artist," no doubt good advice ("Psychology and Literature" par. 161). Apparently Freud and Jung were able to do so. They both found fundamental inspiration and insight for their psychological theories in their readings of imaginative literature. Freud famously brought Sophocles' portrayal of a son's unconscious weddedness to his mother to collective consciousness. Jung in Memories, Dreams, Reflections credits Goethe's Faust with his insight into the existence of shadow (235). ${ }^{1}$ Fortunately, one doesn't have to be a Freud or a Jung to receive some of the psychological enlightenment literature has to offer. I myself came conceptually upon the existence of the realm of psyche beyond ego in my reading of imaginative literature long before I had read Jung's descriptions of the unconscious. I learned of the confines of ego through a rather mystical experience reading Mark Twain's "The Mysterious Stranger," an ego-disorienting story that for an all-too-brief hour freed me utterly from the ego constraints of fear, from certainty of my world view and the assumptions upon which it was based, and from habitual unconsciousness of my mortality. It was an amazing experience that made the multiple dimensions of psyche real beyond dispute for me. 
For those who have not read Twain's story, let me try to suggest the disorienting power of its strangeness. The mysterious stranger turns out to be a young man named Satan, nephew of the infamous Satan, who introduces himself to a group of boys in medieval Austria whom he befriends. He is possessed of marvelous powers. He can create life and can even loan that power to others. He enables the young boys to make small living creatures, who, since the boys are utterly inexperienced, turn out to be lopsided, pathetic cripples. Satan wipes them away with a swipe of his hand, stunning and sobering the boys. His nonchalant massacre also stunned and sobered me.

Besides creating people, Satan can alter the fate of a person by changing a single act. He claims that everyone's life is determined by his or her first act, each life a row of bricks lined up and falling sequentially one upon another. The only way anyone's life can be changed is through supernatural intervention such as his own, altering a particular act. He changes the fate of characters, who then, to the boys' horror, either die early or go mad. He defends the compassion behind these fates by pointing out that those who die early avoid lives of misery, while those who go mad have the possibility of happiness, a possibility, he claims, not available to the sane. These reversals were also stunning.

Satan, who can travel through space and time in an instant, dispenses his scalding views of human beings while taking the boys on tours of earth, of heaven and hell, of human history. He continuously underscores humanity's self-delusions, cruelty, violence, superstition, senseless conformity, and pretentiousness, all of which were a heavy dose of shadow revelation to me, still immersed in idealism.

At the end of the tale, Satan comes to say good-by to the narrator and gives him his final lesson. He spews a relentless condemnation of what he conceives as the human understanding of God, accusing God of not using his powers for human happiness, but instead making bad human beings who although they suffer want to live and are forced to die. Satan's rant peaks with a condemnation of God's double standards, particularly as regards forgiveness. He says, "God mouths. . . the Golden Rule and forgiveness multiplied by seventy times seven, and invented hell; . . and finally, with altogether divine obtuseness, invites this poor, abused slave to worship him! ..." (252-53). I, whose personal struggles had long led me to question the goodness of God, felt my hopes of God being exploded, becoming floating fragments of ideas.

Such a divinity, Satan insists, proves that human beings live in a dream: "You perceive, now, that all these things are impossible except in a dream. You perceive that they are pure and puerile insanities, the silly creations of an imagination that is not conscious of its freaks-in a word, that they are a dream, and you the maker of it" (253). This dream, Satan says, includes not only God, but everything - the afterlife, all living beings, the stars, Satan, himself. He climaxes his last teaching by 


\section{Martinez}

revealing that not only is what humans believe to be reality a mere dream, but that the dreamer also has no substantiality, is merely a lost, wandering thought:

"It is true . . . : there is no God, no universe, no human race, no earthly life, no heaven, no hell. It is all . . . a grotesque and foolish dream. Nothing exists but you. And you are but a thought-a vagrant ... useless thought, wandering forlorn among the empty eternalities!" (253)

Most disorienting of all, Satan claims that the nihilistic vision he is imparting is the gift of psychological freedom. As he disappears, he prophecies eternal solitude for the dreamer, but also the possibility of dreaming a better dream:

"I am perishing ... you will be alone in shoreless space, to wander its limitless solitudes without friend ... forever-for you will remain . . . the only existent thought, and by your nature inextinguishable, indestructible. But I, your poor servant, have revealed you to yourself and set you free. Dream other dreams, and better!" (252)

And so he had-set me free-from my normal ego consciousness. For at that moment, imagining Twain's fictional world in "The Mysterious Stranger" distanced me from every grounding perspective I had on life and on my experience, revealing them as arbitrary rather than natural and inevitable. Paradoxically, the line, "Life itself is only a vision, a dream," put me more in touch with my experience of living life than I had ever been-for I grasped that my understanding of life was merely a fiercely held description, and as the unconscious assumption that my version of the real was reality fell away, I found myself in a psychological space and series of moments in which existence was all.

So fully was I alive that I felt absolutely no fear. This wondrous state made me aware that I lived my life in the presence of a continuous unconscious fear, much as I lived with gravity and never noticed it. Its disappearance left me with exhilarating joy. I remember sitting up in my bed, looking at the walls, and feeling that my existing where I was-room, state, hemisphere, at this moment, in this culture and century - was totally arbitrary. In other words, my living as I was seemed in no way necessary. My living at all was cause of amazement, the ultimate happy surprise. I existed fearless, joyous, and did so in a new, absolute certainty that I would one day die. Instead of fear, I felt elation. How extraordinary it was for me to be alive when it was certain that within a puff of time, I would be dead.

I was so young that I had not yet grasped that all things pass. I assumed that this fearless elation would last and was happily planning the joy with which I would live the next day, beginning with the seminar. But within minutes, the clarity of vision, the freedom from fear, the joy were gone. 
Still, I now knew that what I have come to call ego consciousness is a limited psychological state and that psyche is a much larger reality of whose existence I had lived unconscious. Although that experience has never been repeated, I have since in less extraordinary ways encountered the "Other" while reading literature.

Yet we know that many readers do not discover psyche beyond their normal ego consciousness during their readings of imaginative literature. Reader blindness to the manifestations of unconscious psyche in literature I call ego readings. The phrase is somewhat misleading because, of course, all readings involve the ego complex. Still, I find "ego reading" a convenient shorthand for those readings that occur without the loosening of ego controls. Ego boundaries must relax for imaginative literature to work its transformative magic - a realization that many critics have voiced. As Marga Speicher's study of the psychological influences of literature records, early literary explorers of the significance of the unconscious in reading literature such as Ernst Krist, Norman Holland, and Gilbert Rose, ${ }^{2}$ have written of the need. Indeed the most original and comprehensive of contemporary Jungian literary critics, Susan Rowland, has also insisted that the unknowable unconscious requires that "the reader renounce ... fantasies of control" (C. G. Jung and Literary Theory 38). What I am offering is a name for what happens when we read without our ego boundaries becoming porous, signposts of that state, and some suggestions about how we might slip free of it.

Of course, before we attempt to escape the constraints of ego readings, we must absorb their many values. They can contribute to the development of one's ego, a necessary early step in the development of the personality. This stage necessarily involves inflation, that is, thinking oneself more-more invulnerable, more influential, more powerful, more right - than one is. Ego readings are based on the illusion that what one knows and believes describes what is-more, that they describe what matters in what is. Thus one is not surprised to see the greatest writers and thinkers of all time mirroring back to oneself one's own ideas. Ego readings can even serve to strengthen one's capacities for consciousness. As one becomes increasingly grounded and secure in one's point of view (aware that it is a point of view), the ability to face and tolerate another's presumably would be strengthened.

Unfortunately, judging from the history of literary criticism, ego readings more typically lead to deeper entrenchment in belief in the superiority of one's own limited perspectives. Somehow, once we have finally had an idea, it seems very hard not to attach to it as the best idea around. Literary criticism is probably as good a place as any to start identifying when one is caught in ego reading.

The literary critic Gerald Graff, the 2008 President of the Modern Language Association, in an essay in Falling into Theory, a book about how to teach literature to underclassmen by introducing them to theoretical debates among literary critics, confesses that he, himself, once found literature intransigently 


\section{Martinez}

boring. It was not until he learned that there existed debate as to the meanings of texts that he became interested. As he read critics' arguments with one another, it occurred to him that "perhaps it would not be so bad after all to become the sort of person who talked about "cultural contradictions." He muses, "Perhaps even mere literary-critical talk could give you a certain power in the real world" (39) [emphasis added]. Graff's honest claiming of the desire for power testifies to his reading literature for ego gratification. His statement is an unusual admission of literary criticism's normal foundation in argumentation, that is, in competition, and thus in power struggle, the turf of the ego.

One might think that the development of poststructuralism and deconstruction would have made ego readings déclassé. As Rowland points out in Jung as a Writer, these developments undercut the authority of the author, invited readers to be aware of multiple voices in texts, and clarified that meaning is plural (108). Yet deconstructive hermeneutics can be as vulnerable to ego readings as old-fashioned biblical exegesis. Using Barbara Johnson's excellent analysis in The Critical Difference, I offer as example a series of readings of Edgar Allen Poe's "The Purloined Letter." In his "Seminar on the Purloined Letter," Jacques Lacan did a classic ego reading of Poe's story by mapping onto it various of his Neo-Freudian beliefs. Poe's story hinges on a presumably incriminating letter stolen from the Queen by the Minister in the presence of an unnoticing King. The protagonist, Dupin, must find the missing letter. Lacan uses Poe's story to buttress the idea he appropriated from Ferdinand de Saussure that the signifier, in this case the letter whose contents are never revealed, is the source of meaning and power. Jacques Derrida, in "The Purveyor of Truth," illustrating the powers of a deconstructive reading, criticizes Lacan's reading for failing to include the context of Poe's other Dupin stories and for making the signifier the content of the story, thus missing its many other unfolding possibilities (ctd. in Johnson, 113-17, 153). ${ }^{3}$ After establishing the differing readings of Poe's story by Lacan and Derrida, Johnson indicts Derrida's response. She writes:

... Derrida's own reading of Lacan's text repeats the crimes of which he accuses it; . . . Derrida makes no mention of Lacan's long development on the relation between symbolic determination and random series. And ... Derrida dismisses Lacan's style as a mere ornament, veiling, for a time, an unequivocal message. . . . (116)

Through her critique of their readings and her description of the two of them engaged in ego-jostling for credit for ideas, ${ }^{4}$ Johnson stakes her claim as the most able interpreter of them all. In their respective texts, all three readers, Lacan, Derrida, and Johnson apparently write from ego desires for interpretive hegemony. ${ }^{5}$ 
Hermeneutics as the professional practice of literary criticism endures ego readings as a professional hazard.

Academic reading in general, because it reads texts to make arguments, is typically dominated by the ego. Literary criticism as an academic pursuit is particularly hobbled from reading for psyche. Academically, critics must read to formulate concepts they can back up. But a concept by itself is not an experience of the Other, the unconscious content, of imaginative literature. The role of feelings in the process of that encounter is crucial. Jung recognizes their importance in his discussion of the impotence of ideas without them. He says that an idea requires an "affect that is ready to seize hold" of it. Otherwise, "An idea ... is nothing but an intellectual counter that can have no influence on life, because in this state it is little more than an empty word" ( $C W$ 8: par. 634). Because imaginative literature engages emotions through narrative and sensuous language, reading it is not merely a sequence of cognitions. Reading for the "Other" requires an openness to the text as physical, emotional, and conceptual experience of what one does not yet know. Yet academic literary critics because of the conventions of academic discourse as argumentation must focus their reading to find proof for their thoughts. Thus we have the anomaly of a professional practice that can inhibit experiencing the transformative power of its subject matter.

Fortunately, most readers of imaginative literature are not academic literary critics. Most read consciously for pleasure, a cause and consequence of ego readings. Such readings yield the ego pleasures of affirmation of one's point of view, of one's ability to understand, to criticize, to be superior, to be in control. They do not require staying with the uneasiness stirred by any new perspective, do not challenge one to be open to change. But beyond such comfortable pleasures, there are also the deeper gratifications of the soul's breaking through habits of consciousness. To receive the visions latent in literature, readers' ego boundaries must loosen so that readers may be open to perceiving that of which they have been unconscious.

Since the workings of the unconscious are limitless in the sense that their extent is unknown, I shall not even begin here to explore the mysteries of the many ways literary revelations of unconscious psyche elude ego repression, although that, no doubt, is the more fascinating question. ${ }^{6}$ Instead, I will limit my attention to a few enabling interventions consciousness might make to help loosen ego boundaries, beginning with the idea that one can become aware of performing an ego reading.

This awareness depends upon some sense of the reality of psyche as larger than one's ego perspective. As Jung writes when referring to unconscious archetypes: "You can know all about the saints, sages, prophets . . . and all the great mothers of the world. But if they are mere images whose numinosity you have never experienced, it will be as if you were talking in a dream, for you will 


\section{Martinez}

not know what you are talking about" (Man and His Symbols 98). As my experience with Mark Twain's "The Mysterious Stranger" illustrates, literature itself can initiate one into multiple dimensions of psyche, so it is not essential for readers to bring that awareness with them, but if they already have it, they can read consciously open to encountering the Other in the text.

What are the clues that readers are reading with taut ego boundaries? As the Lacan-Derrida example makes clear, finding what we already think in a text is evidence of an ego reading. If we encounter what we already know in text after text, chances are we are not reading what is there. We can know that we have received the "Other" when we have a new experience challenging us to develop a new understanding.

In terms of imaginative literature, a very popular form of ego reading is reading primarily for plot. Discovering what happens next, as if a sequence of events were the point, confirms the ego's belief in cause and effect, the rational basis of a sense of control. Further, reading for plot obstructs other questions of possible meaning, thus shunting psychological meanings out of the reading experience. There then will be little threat to the ego's assumptions that it knows what needs to be known. If we find ourselves reading mainly for plot, we probably either have chosen works limited to conventional consciousness or are defended against psychological meaning in the text.

One such defense is out and out denial. As a reading practice, denial frequently takes the form of omitting from consideration aspects of a text that contradict one's interpretation. It is of course easier to see this resistance in others than in oneself. I had a colleague who read The Color Purple as if the incest described in the beginning of the novel were the character Celie's fantasy. He had good precedent in Freud's having postulated that female patients claiming to have been sexually violated in childhood were fantasizing. Despite the fact that the plot insists that children from the rapes exist, grow up, and eventually are reunited with Celie, my colleague denied the sexual history recorded in the beginning of the book and thus could not virtually experience the transformation of the rapist or of the rapist's and Celie's relationship.

I suspect that the denials in my own readings tend toward seeing parody where most readers see none. When I read the Iliad, for example, the animal comparisons, the deviousness and cruelty of the warriors, and the limitations of the gods all seemed to me to indicate that the vision conveyed by the Iliad is anti-war. That reading, I acknowledge, shows my denial of the human capacity to revere warmaking. Of course, there are no doubt many readings I have done in which denial has come into play of which I am not yet aware. The point is that seeing parody for 
me is a clue that I might be resisting a portrayal of psyche that would be illuminating if taken seriously.

For those able to recognize the Other in a text, an expressive sign of ego readings often erupts: anger at the text. If a text offends, one's ego defends. That is the moment when to go beyond ego readings one may surrender to the text and allow its materials to enrich one's experience and understanding-or not. One scenario, but only one-the possibilities are legion-in which these moments typically arise occurs when a group with which one identifies is being portrayed badly. I have found my own resistance most frequently to arise over the question of how a text portrays women. In an effort to avoid the limitations of ego reading, it seems incumbent upon me to try to see beyond what strike me as vicious portrayals. D. H. Lawrence's short story, "The Rocking Horse Winner," for example, depicts an upper middle-class mother who, "when her children were present . . . always felt the center of her heart go hard" (889). Lawrence characterizes this loveless woman as insatiably desirous of money, a greed that drives her son to ride his rocking horse to his death in his efforts mysteriously to discover winners of derbies and thus win money to earn his mother's love. $\mathrm{He}$ grows too old for his rocking horse yet keeps it and continues to ride it again and again, madly, until the moment of inspiration, suggesting masturbatory orgasm. When I began the story, the negative depiction of the mother, accomplished in the very first paragraph, irritated me. Had I stopped there, I would have missed the power of Lawrence's rendering of the son's compulsive quest, his futile sacrifice of his sexual and life energy to earn what can only be given. I would have missed the symbolic power of the rocking horse-a child's toy, a wooden simulation of life, inherently fated to repetitive movement, incapable of forward movement, the means of compulsive masturbation, imaging the son's arrested development. Resistance is a clear sign that one's ego boundaries are tight and threatened, implying new vision may lie just beyond.

I do not wish, however, to finesse the ethical dimension of attempting to loosen ego boundaries when one feels threatened by a text. One of the ego's most defining functions is to respond ethically. Being open to the "Other" of the unconscious in a text will at some point if not almost always expose one to values to which one is ethically opposed. The question then becomes whether one's own values need reassessment or whether the "Other" one is encountering needs to be resisted. Texts convey not only unconscious psychological visions that might compensate for the limitations of current consciousness, but also ideological and ethical implications. Reader resistance might emerge from the normalization or reification of a destructive ideological perspective. Rowland, for example, offers a critique of Hopeful Monsters by Nicholas Mosley in which she argues that Mosley's vision fails to question the power relations between writer and reader (C.G. Jung and Literary Theory 146). This failure, she argues, leads to his 


\section{Martinez}

colonizing the reader into his beliefs about the desirability of transcending the body (143), in particular the body of the mother, and his beliefs about Jung as transcendent theorist (155). From her postmodernist perspective, Rowland discerns value distortions in Mosley's text. This discernment is a function of ego reading, a function necessary for assuming ethical responsibility for one's interpretations of texts.

The ego's work of taking ethical responsibility while reading also involves being responsible to and for one's own soul. Recently I attempted to read Roberto Bolano's 2666, a novel that has received high critical praise. His fourth chapter of five details the physical tortures, sexual violations, and murders of over a hundred women. After the first few descriptions, I asked myself if I should continue. The descriptions were painful and frightening for me to read. I could not imagine an author choosing to focus his imagination on such descriptions again and again. Why would he do it? What possible compensation from the unconscious could be contained in the continuous composing of graphic violence enacted upon women otherwise irrelevant to the story? A friend suggested that he was merely making psychologically inescapable the actual horrors going on in Mexico in sequential murders of women. Even so, his renditions included such a shocking variety of ghastly details that it seemed he was savoring the imaginative effort. I forced myself to continue, although I confess that I began to skip the paragraphs beginning with the finding of another body. I continued because I thought that this was a test case of my own beliefs about loosening ego boundaries.

It has now been some months since I finished the novel, and the change I note in myself is intensified fear. Is the novel to compensate a collective denial and/or dismissal of ongoing violence toward women? Are terror and horror what must be endured to activate consciousness of and resistance to murders of women? I cannot yet decide if I failed in my responsibility to myself in continuing to read Bolano's novel or if I participated in immersion in a horror necessary for collective selfregulation.

This process of attempting to reduce ego control while reading clearly is not to be taken lightly. The ethical dilemmas that loosening of ego boundaries pose, however, do not vitiate the importance of seeking to read imaginative literature for psychological contents of which we have been unconscious. Rather they reflect the tension between responsibility to oneself and to Other that permeates life. Reading is not exempt from the necessity of conscientiously negotiating this tension. This negotiation is part and parcel of the effort to read for psyche.

Having identified various ways of recognizing that one is performing an ego reading - consistently finding what one already thinks, reading for plot, denying what is in a text, omitting consideration of aspects of a text that contradict one's 
interpretation, becoming angry at a text, feeling threatened by a text-I would now like to turn to tools available to consciousness to help read for psyche.

Perhaps the most useful tool is attention. As one becomes aware of being blinkered by one's ego, one can seek to remove the blinkers by reading with focused attention. Virginia Woolf conveyed to me the role of attention in the discovery of the reality of the Other in her unusual short story, "Kew Gardens." In that tale the protagonist is the Gardens themselves, a verbal painting of the garden of life, a garden that includes the cityscape and human beings as its plants and blossoms, its patterns of color and light. Midway through the story Woolf records a conversation between two working class women. Note that it is not a literal transcription of how people speak:

My Bert, Sis, Bill, Grandad, the old man, sugar

Sugar, flour, kippers, greens

Sugar, sugar, sugar. (32)

Like an abstract painter, Woolf reduces this conversation to its basic elements, people and food, showing how words can function as reassurances of the familiar. The continuous exchange of familiar phrases and ideas comforts with illusions of knowledge and control, with socially enacted repetitions of our existence and of our place in our culturally constructed world. Conversation becomes a form of quasi-conscious behavior.

Woolf describes one of the women suddenly losing track of the words in a numinous moment of actually attending to a patch of flowers. For that moment, she is caught up in what Woolf describes in A Room of One's Own as an experience of reality (113-14) — an instant of being consciously present:

The ponderous woman looked through the pattern of falling words at the flowers standing cool, firm, and upright in the earth, with a curious expression. She saw them as a sleeper waking from a heavy sleep sees ... and stares ... with all his powers. (32-33)

After implying that normal consciousness is a state of relative unconsciousness, Woolf proceeds to describe the moment of presence as one of total concentration of attention:

So the heavy woman came to a standstill opposite the oval-shaped flowerbed, and ceased even to pretend to listen to what the other woman was saying. She stood there letting the words fall over her, swaying the top part of her body slowly backwards and forwards, looking at the flowers. (33)

The character then slips back to the quasi-consciousness of her normal state. What allows her to encounter the "Other" is attention. Similarly, concentrated attention makes more likely encountering the Other while reading literature. Also, quantity as well as quality of attention matters. I have found that rereading texts 


\section{Martinez}

that have struck me as psychologically rich yields the most hope for integration because re-reading expands and refines the conceptual grasp of what is occurring within me. Concepts, when occurring as a result of encountering the Other in imaginative literature, are the climactic contributions egos can make to the development of consciousness. I use "consciousness" here to mean understanding that integrates bodily, emotional, and cognitive knowledge.

Another tool for reading for psyche is to do so intentionally. This intention quickens becoming sensitive to the moments when one is "struck," as I put it, with the psychological richness of a text. These moments can manifest in endless ways, but one obvious one occurs when the text itself narrates a numinous event, such as the woman's seeing the flowers. Being "struck" often means the reader has been led to a numinous question or insight. I use "numinous" here to mean momentarily escaping the cage of one's assumptions about reality, enabling one to wonder, perhaps even to see, beyond one's certitudes. ${ }^{7}$ One can be gifted with more of these moments when one reads with the intention of discovery.

No single framework can account for a text's numinosity for all readers, but the experience can be recognized and, once recognized, reflected upon. Reflection, finally, is the magic tool bringing to consciousness what has breathed unconsciously in the text-reflection, that ineluctable process of turning attention, feeling, time, inner quiet, to a subject to allow the intimations of thoughts and the emotional vibrations of connections to arise in consciousness.

To recapitulate, once one is aware of performing an ego reading, one can seek to slip free by concentrating one's attention, re-reading, watching for moments of psychological import in a text or unfamiliar stirrings in oneself, and then taking time to reflect so that unconscious materials may pass the threshold into consciousness.

While any new understanding made possible by a text occurs reader by reader, the special promise of literature is that, unlike a dream, it is available to the reading collective. Literature's public life makes possible Jung's claim that it can influence collective consciousness. His specific claim, however, that literature emerges from the collective unconscious and offers compensatory understanding to collective consciousness is difficult to substantiate because it is not possible to isolate a single cause for collective transformation. The best one can do, I believe, is to offer an example of a literary work's contributing to such a change.

Let me share an instance of such a transforming book in cultural history. Robert Browning's The Ring and the Book published in 1868-69, a narrative poem, consists of ten dramatic monologues in which different speakers offer their conflicting versions of a murder. To the horror of Browning's readers, the narrator does not provide a "true" version. For example, in describing the point of view of 
one of the speakers, Half-Rome, the narrator says, "'Tis there- / The instinctive theorizing whence a fact / Looks to the eye as the eye likes the look" (20). The Ring and the Book aroused scandalized accusations of Browning's befuddling truth. Thomas Carlyle said to Browning's face: "that of all the strange books produced in this distracted earth, by any of the sons of Adam, this one was altogether the strangest and the most preposterous in its construction; and where ... do ye think to find the eternal harmonies in it?" (Wilson 6: 176). Browning's use of various viewpoints in The Ring and the Book led the philosopher George Santayana to call the monologues "monstrous" (73). He was offended by Browning's failure to "clarify ideas and disentangle values" (72). Readers' experience of obscurity in Browning's poems contributed to the development of the London Browning Society in 1881 and its offshoots in America such as the Chicago Browning Society in 1882. These clubs were formed and instructional pamphlets produced to help readers understand Browning's poems. ${ }^{8}$ The cofounder of the London Browning Society, F. J. Furnivall, wrote in a letter to the Boston Literary World that "Our main reasons for starting the Society were that the manliest, strongest, deepest, and thoughtfullest Poet of our time . . . needed interpreting and bringing home to folk ..." (qtd. in Peterson 10-11).

By the time I read The Ring and the Book, the idea it conveys that viewpoint is partial and that therefore no one can see anything entire or have complete access to "truth" was part of the culture in which I had grown up. It had become part of collective consciousness. Of course, I do not attribute this shift simply to Browning's poem. Conceptual developments in economic theory, such as Marx's insisting upon the influence of class on ideas; in science, such as Heisenberg's Uncertainty Principle stating the impossibility of measuring location and momentum of a subatomic particle at the same time; and in psychology, such as Freud's giving currency to the concept of the unconscious, to name only a trio of the most influential ideas, shaped our collective understanding of the inherent limitations of viewpoint. I want to claim only that Browning's poem was a significant moment in the process whereby the inevitable partiality of any single perspective has come to be recognized. The Ring and the Book posed an aspect of unconsciousness for discovery by collective consciousness. Further, the aspect it presented assists tolerance of difference which in turn, I suggest, contributes to the self-regulation of collective psyche.

Literature can further collective consciousness even when an author is writing about a psychological issue that is deeply personal. The writings of Jorge Luis Borges provide an example of a contemporary connection between a personal issue and a collective crisis - the very loss of unitary truth portrayed by Browning. In an interview, Borges speaks of a recurring nightmare:

That is a nightmare of trying to read and of being unable to because the characters become alive, because every letter turns 


\section{Martinez}

into other letters, and then the words at the beginning are short when I try to make them out. They are long Dutch words with repeated vowels. Or, if not, the spaces between the lines widen out, and then the letters are branching out, and all that is done in black or red characters, on very glossy paper, and so large as to be intolerable. And when I wake up, those characters keep me company for some time. Then for a wild moment I think, I'll never be able to forget them and I'll go mad. ${ }^{9}$ (Burgin 182)

This nightmare leads Borges to seek control of ever proliferating narratives and meanings in stories such as "The Garden of Forking Paths," "The Library of Babel," and "The Secret Miracle," stories narrating the search for some sort of totality in relativistic worlds. The totality being sought is a textual container of all knowledge and all possible knowledge, containers such as a single book, a single library, a single word. These stories mirror the twentieth-century dilemma of loss of absolutes and transcendents, of the relativising of history and truth into endlessly fissioning texts. Borges's nightmare images a collective dilemma. As Jung remarks in Two Essays in Analytical Psychology, "Neurosis is thus nothing less than an individual attempt, however unsuccessful, to solve a universal problem; indeed it cannot be otherwise, for a general problem . . . exists only in the hearts of individuals" ( $C W$ 7: par. 438). One way literature seems to contribute to the process of helping the collective psyche self-regulate is by imaging unresolved traumas.

In the beginning of this essay, I puzzled over why human history has been so marked by moral horror if a means of regulating the collective psyche has been available in imaginative literature. In partial answer, I've pointed out that a reader's construction of meaning can serve merely to reinforce limited ego consciousness. For transformation to occur, we need to comprehend that literature is a primary source for understanding psyche. We also have to grant that our current state of consciousness is limited and in need of development. Then we can seek to recognize when we are doing ego readings and can use the tools of attention, intention, and reflection to loosen our ego boundaries so that we may discover and ponder what the creative unconscious has revealed through artists in their art.

Because each reader is both limited and particularly enabled by his or her specific experiences and knowledge, the degree of harvesting imaginative literature for its revelations depends upon how many of us succeed in reading for psyche. Consequently, a society's attitude toward the reading of literature is crucial.

I wish to conclude by suggesting that current teaching of literature at the high school and college levels typically works against readers learning to read for psyche. As recently as 2008, the previously mentioned MLA President Gerald Graff used his position to seek to institutionalize what I am calling ego readings. 
He advocated teaching literature through having students read secondary sources, criticism, in order to argue against critics. In a "Presidential Column" in the $M L A$ Newsletter dedicated to the subject of teaching literature students how to write a paper, he describes "a silent battle for the soul of the literature classroom . . . being waged between those who want students to engage with critics and those who want them to "just read the works"(4). Graff's vision suits literature as a profession well, in that it harnesses institutions of education into providing a captive audience for literary criticism, and it trains students to think that the purpose of reading literature is to write argumentative papers in response to literary criticism. This entire enterprise is in the service of ego readings and is oblivious of literature's powers of psychological transformation. Graf's influence is merely illustrative of various approaches to the teaching of literature that bypass its psychological significance.

If literature contains materials of which the collective is by and large unconscious and in need of bringing to consciousness, then both the teaching of literature and the writing of criticism should encourage reading for psyche. Certainly, Jungian literary criticism can take the lead in approaching literature as a source for revealing psyche and can thus contribute to increased integration of the unconscious contents latent in imaginative literature. Jungian literary professors have a calling not only to write criticism resulting from reading for psyche, but to explore ways of teaching this approach and sharing best practices. For imaginative literature to assist not only individuals, but, as Jung hoped, collectives, selfregulate, readers need to know the difference between doing ego readings and reading for psyche. ${ }^{10}$

\section{Works Cited}

Bolano, Roberto. 2666. Trans. Natasha Wimmer. New York: Farrar, Straus, and Giroux, 2004. Print.

Browning, Robert. The Ring and the Book. 1868-69. New York: Norton, 1961. Print.

Burgin, Richard, ed. Jorge Luis Borges: Conversations. Jackson MS: UP of Mississippi, 1998. Print.

Derrida, Jacques. Positions. Paris: Minuit, 1972. Print.

Graff, Gerald. "Disliking Books at an Early Age." Falling into Theory: Conflicting Views on Reading Literature. Ed. David H. Richter. Boston: Bedford, 1994. Print.

---. “How ‘bout That Wordsworth!” Presidential Column. MLA Newsletter Winter 2008: 3-4. Print.

Holland, Norman. The Dynamics of Literary Response. New York: Oxford University Press, 1968. 63-103. Print.

Johnson, Barbara. The Critical Difference: Essays in the Contemporary Rhetoric of Reading. Baltimore: Johns Hopkins UP, 1980. Print.

Jung, C. G., and M.-L. von Franz, Joseph L. Henderson, Jolande Jacobi, and Aniela Jaffé. Man and his Symbols. Garden City: Doubleday, 1964. Print.

---. Memories, Dreams, Reflections. Ed. Aniela Jaffé. Trans. Richard and Clara Winston. 1961. New York: Vintage Books, 1965. Print. 


\section{Martinez}

---. The Spirit in Man, Art, and Literature. CW. 19 vols. Trans. R.F.C. Hull. Ed. Read, Sir Herbert, Michael Fordham, Gerhard Adler, and William McGuire. Bollingen Series XX. Vol. 15. Princeton: Princeton UP, 1966, $2^{\text {nd }}$ ptg. 1972. Print.

---. Two Essays in Analytical Psychology. CW. 19 vols. Trans. R.F.C. Hull. Ed. Read, Sir Herbert, Michael Fordham, Gerhard Adler, and William McGuire. $2^{\text {nd }}$ ed. rev. 1966. Bollingen Series XX. Vol. 7. Princeton: Princeton UP, 1953.

Kris, Ernst. Psychoanalytic Explorations in Art, New York: International Universities Press, 1952. Print.

Lacan, Jacques. Ecrits. Paris: Seuil, 1966. Print.

Lawrence, D. H. “The Rocking Horse Winner." 1933. The Story and Its Writer: An Introduction to Short Fiction. Ed. Ann Charters. Boston: Bedford/St. Martins, 2003. 889-900. Print.

Peterson, William. Interrogating the Oracle: A History of the London Browning Society. Athens: Ohio UP, 1969. Print.

Rose, Gilbert J. “The Creativity of Everyday Life.” Between Reality and Fantasy. Ed. Simon A. Grolnick and Leonard Barkin in collaboration with Werner Muensterberger. New York: Jason Aronson, 1978. 347-362. Print.

Rowland, Susan. C. G. Jung and the Literary Experience. New York: St. Martin's, 1999. Print.

---. Jung as a Writer. London: Routledge, 2005. Print.

Santayana, George. "The Poetry of Barbarism." 1900. The Browning Critics. Ed. Boyd Litzinger and K.L. Knickerbocker. Lexington: Kentucky UP, 1965. 56-76. Print.

Speicher, Marga. "Letters to Claudia: On the Contributions of Literature to Psychological Growth." Diss. Union Graduate School of the Union for Experimenting Colleges and Universities. Cincinnati, Ohio, 1985. Unpublished typescript at Kristine Mann Library, New York.

Twain, Mark. The Mysterious Stranger and Other Stories. 1916. New York: Signet Classic, 1962. Print.

Wilson, David Alec. Carlyle. 6 vols. London: Kegan Paul, Trench, Trubner, 1923-27. Print.

Woolf, Virginia. A Room of One's Own. 1929. New York: Harvest, 1957. Print.

---. “Kew Gardens." 1919. A Haunted House and Other Short Stories. 1944.

New York: Harvest, 1972. Print.

\section{Notes}

${ }^{1}$ Jung writes that Faust "awakened in me the problem of opposites, of good and evil. ... The dichotomy of Faust-Mephistopheles came together within myself into a single person, and I was that person" (235).

${ }^{2}$ Kris analyzes the shifting relations of ego to unconscious material in writer and reader, terming them inspiration and elaboration (56-61). Holland describes the safety of the reading position as enabling a loosening of ego boundaries allowing reader introjections of the author's fantasies (45-49). Rose offers an interpretation of how the ego goes through a process of separating, fusing and discriminating again (352-55) that Speicher applies to reading (52-53). Rose is applying Winnicott's idea of transitional objects to an explanation of the creativity of everyday life. 
${ }^{3}$ Let me quickly acknowledge that both Lacan and Derrida are formidable instances of thinkers who sought to discover the unknown in psyche, Lacan to make it more intelligible (e.g., the unconscious is structured as a language), Derrida to expand any conception of intelligibility (e.g., meaning is never fully present). My example concerns their respective readings of a short story in which each perceives what he already thinks. When a thinker has hit upon a new formulation such as Lacan's ascription of the symbolic phallus as the signifier of the symbolic order, and Derrida's analysis of texts for what is not purposely said, it makes sense for them to seek confirmation of their ideas in their readings. Seeking confirmation of an idea is a kind of ego-reading that is fundamental to scholarship. I myself am using ego readings, such as this comparison of Lacan's, Derrida's, and Johnson's readings, to argue for the practice of reading for psyche. Limiting oneself to ego readings while reading imaginative literature, however, is like passing through a treasure trove without noticing.

${ }^{4}$ After indicting Derrida's essay for the same faults Derrida claims to see in Lacan's, Johnson goes on to argue that the two of them are merely repeating the rivalry pattern in Poe's story. She quotes from Derrida's Positions (112-13) the following: "At the time of my first publications, Lacan's Ecrits had not yet been collected and published" (118). She then quotes from Lacan's Ecrits (11) Lacan's similar claim which alludes to Derrida's Of Grammatology: "what I properly call the instance of the letter before any grammatology" (118) to prove that Lacan, too, is claiming priority.

${ }^{5}$ Rowland has persuasively argued that Jung shows hermeneutics as fundamental to understanding psyche: "Jung's psyche .... is about the arts of constructing meaning" (Writer 83).

${ }^{6}$ For an influential attempt to identify some of the ways readers interact unconsciously with texts, see Wolfgang Iser's The Act of Reading: A Theory of Aesthetic Response.

${ }^{7}$ I am aware of the religious etymology of the term "numinous." Using the term psychologically, however, broadens its applicability, I believe, to all those moments when the ego encounters a reality beyond its assumed understandings. These moments are precisely the ones enabling reading for psyche.

${ }^{8}$ See the Chicago Browning Society's Robert Browning's Poetry, 1886, for an example of the sort of pedagogical material made available to reading clubs studying Browning.

${ }^{9}$ I am grateful to Prof. Robert Blaisdell for bringing these materials to my attention.

${ }^{10}$ A version of this article was originally part of a book-length manuscript entitled "Reading for Psyche" which contained literary interpretations explaining the title phrase. The absence of such a context may lead some readers to wish to see examples of what I mean by reading for psyche. My published articles illustrating this practice include: "Reading for Psyche: Joseph Conrad's The Secret Sharer, Portrait of Shadow Integration," upcoming in Quadrant; "Toni Morrison's Beloved: Slavery Haunting America," JUNG: the e-journal of the Jungian Society for Scholarly Studies. 4.3 (2008): 43. http://www.thejungiansociety.org/; “Haruki Murakami's 


\section{Martinez}

Reimagining of Oedipus in Kafka on the Shore," Psyche and the Arts. Ed Susan Rowland. London: Routledge, 2008, 56-65; "'Sonny's Blues' and Cultural Shadow," JUNG: the e-journal of the Jungian Society for Scholarly Studies. 3.2 (2007): 13. http://www.thejungiansociety.org/; "Reading for Psyche: Kate Chopin's The Awakening," Harvest: International Journal for Jungian Studies, special issue on Jung, Art, and Literature Vol. 50, No. 2 (December 2004): 104-17; "Flannery O'Connor and the Hidden Struggle of the Self," The Flannery O'Connor Bulletin 16 (1987): 52-61; and "The Lesbian Hero Bound: Radclyffe Hall's Portrait of Sapphic Daughters and their Mothers," Literary Visions of Homosexuality. Ed. Stuart Kellogg. New York: The Haworth Press, 1983, 127-37.

My own practice has typically been to begin with a psychological concept a text seems to call forth as a gateway into reading the text so that the psychological abstraction could be elaborated and differentiated through a particularized literary portrait. When I read Rowland's claim that "the literary text becomes the site of the testing and challenging of psychological writing ( $C$. G. Jung and Literary Theory 1 ), I thought my practice fell within her generalization. Murakami's Kafka on the Shore led me to ideas about psyche I had not found in my reading of psychological theory. Morrison's Beloved led me to postulate unresolved cultural complexes among Americans. I believe it is worth mentioning that the process of peer review has required of me that I revise so as to include arguments in response to other critics, else my work could not be published. 